\title{
Transformational Leadership, Kondisi Kerja, dan Budaya Organisasi Pengaruhnya terhadap Kinerja Karyawan
}

\author{
Siti Mujanah ${ }^{1}$, Siti Nurul Aini ${ }^{2}$, Candraningrat ${ }^{3}$ \\ 1,2Fakultas Ekonomi Dan Bisnis, Universitas 17 Agustus 1945 Surabaya \\ ${ }^{3}$ Fakultas Ekonomi dan Bisnis Universitas Dinamika \\ e-mail: 1sitimujanah@untag-sby.ac.id, ${ }^{2}$ stnurulaini92@gmail.com, ${ }^{3}$ candra@dinamika.ac.id
}

\begin{abstract}
This aims of this study was to find the relationship between transformational leadership, working condition and organizational culture on employee performance. Respondents on this study were employees at Central Asia Raya Surabaya as a sample in the study amounted to 62 peoples. This research used primary data sources with collection data method by survey with a questionnaire instrument, after the data is collected, the data is analyzed using the analysis of correlation, regression, $f$-test and t-test with SPSS software. The results of this study indicate that transformational leadership and working condition and organizational culture partially have a significant effect on employee performance. Furthermore, as simultaneously transformational leadership, working condition, and organizational culture have a significant effect on employee performance, and work environment dominant influence on employee performance.
\end{abstract}

Keywords: transformational leadership, working conditions, organizational culture, and employee performance

\section{PENDAHULUAN}

Sumber daya manusia memiliki peran penting dalam mencapai keberhasilan suatu organisasi terlebih dalam suatu perusahaan. Sumber daya manusia sebagai subjek yang menggerakkan semua aktivitas di organisasi mulai dari merencanakan, mengorganisasikan, melaksanakan, dan mengevaluasi semua kegiatan sumber daya manusia. Untuk itu diperlukan sumber daya manusia yang potensial yang akan berperan dalam melaksanakan kebijakan dan kegiatan operasional perusahaan. Perusahaan harus menciptakan strategi mulai merumuskan visi, misi, tujuan, dan sasaran yang harus dipahami oleh setiap anggota di dalam organisasi.

Untuk mencapai tujuan organisasi diperlukan sumber daya manusia yang potensial yang mampu mencapai kinerja sesuai dengan yang ditargetkan oleh perusahaan demikian juga di perusahaan asuransi yang tingkat persaingannya cukup tinggi.
Perkembangan industri asuransi di Indonesia mengalami peningkatan yang cukup baik yang bisa dilihat dari perkembangannya selama empat tahun terakhir, di mana aset industri asuransi yang mengalami pertumbuhan rata-rata mencapai lebih dari 16\% (Nisrina Salma Alifah, 2020).

Rata-rata pertumbuhan perusahaan asuransi di Indonesia memiliki nilai investasi yang masing-masing ada peningkatan sebesar $14,4 \%$ dan juga $21,0 \%$, sebagaimana disampaikan oleh Kepala eksekutif Pengawas IKNB Firdaus Djaelani (2011). Data tersebut menunjukkan adanya peningkatan positif yang terjadi di dalam bisnis asuransi. Namun demikian Perusahaan asuransi di Indonesia masih bisa ditingkatkan kinerjanya secara optimal guna mendukung pertumbuhan asuransi sehingga setiap tahun dapat meningkat terus. Peningkatan kinerja perusahaan dapat dilakukan dengan meningkatkan kinerja karyawan, semakin tinggi kinerja karyawan akan semakin 
tinggi pula kinerja organisasi atau kinerja perusahaan.

Perusahaan Central Asia Raya Surabaya dalam mengelola SDM selalu memperhatikan kebutuhan karyawan yang mampu meningkatkan kinerja karyawannya. Oleh karena pimpinan sangat berperan terhadap kinerja karyawan. Selain itu, kondisi kerja yang nyaman juga sangat diharapkan dalam meningkatkan kinerja karyawan. Selain kondisi kerja, budaya organisasi juga diperlukan karena banyak penelitian mengatakan bahwa budaya organisasi yang kuat yang diterapkan di perusahaan, dan semua anggota organisasi menerima dengan baik maka diharapkan dapat meningkatkan motivasi karyawan dan pada akhirnya dapat meningkatkan kinerja karyawan.

Berdasarkan fenomena yang terjadi, maka penting untuk di ketahui apakah kepemimpinan transformasional, kondisi kerja dan budaya organisasi berpengaruh terhadap kinerja karyawan dii PT AJ Central Asia Raya Cabang Surabaya.

Keberhasilan suatu organisasi tidak lepas dari seorang pimpinan yang menjalankan fungsinya dengan gaya kepemimpinan yang menjadi ciri kas tersendiri, salah satunya adalah kepemimpinan transformasional yaitu merupakan perilaku seorang pemimpin yang melibatkan perubahan besar dalam memengaruhi sikap dan asumsi anggota organisasi dan membangun komitmen, misi, tujuan, dan strategi organisasi (Robbins, Stephen P. \& Coulter, 2010).

Kepemimpinan transformasional juga dapat diartikan sebagai kemampuan seorang pemimpin dalam menginspirasi dan memotivasi para pengikutnya untuk meningkatkan hasil yang dicapainya (Tria Mondiana, 2012). Pemimpin dengan gaya kepemimpinan transformasional cenderung memberikan lebih banyak kebebasan, rasa kepemilikan dan tanggung jawab yang akan mendo- rong tercapainya tujuan perusahaan yang bersangkutan (Khan, Zunnoorain, \& Shahzad Khan, 2013).

Dengan demikian dapat dikatakan bahwa kepemimpinan transformasional menginspirasi dan memotivasi pengikutnya sehingga pengikut cenderung lebih banyak kebebasan, dan punya rasa memiliki untuk mencapai kinerja yang lebih tinggi (Sekar Nindita Adila Putri dan Dadang Iskandar, 2016), karena kepemimpinan transformasional berpengaruh signifikan terhadap kinerja karyawan (Anhairullah dan Siti Mujanah, 2016), hasil penelitian lain juga menyatakan bahwa kepemimpinan transformasional berpengaruh positif dan signifikan terhadap kinerja (Endri Sukmana dkk., 2015)

Selain kepemimpinan transformasional yang diterapkan, kondisi kerja juga berpengaruh terhadap peningkatan kinerja karyawan (Delvin Alexander Gunawan, 2018). Kondisi kerja merupakan suatu sarana dan prasarana yang dipersiapkan oleh perusahaan di tempat kerja dan yang diharapkan dapat mendukung karyawan dalam menjalankan pekerjaannya (Alex S. Nitisemito, 2014). Definisi lain menyatakan bahwa kondisi kerja merupakan keseluruhan peralatan perkakas dan bahan yang digunakan dalam mengerjakan tugasnya yang berada di lingkungan sekitarnya di mana seseorang bekerja, metode kerja, pengaturan kerja, baik yang dilaksanakan secara perseorangan maupun sebagai kelompok (Sedarmayanti, 2006).

Kondisi kerja perusahaan terdiri dari fisik dan non-fisik, yang berbentuk fisik Yaitu keadaan tempat bekerja dalam bentuk fisik yang disiapkan sebagai tempat bekerja sesuai dengan pekerjaan karyawan, sedangkan kondisi kerja non-fisik adalah keadaan tempat kerja yang berkaitan dengan kondisi hubungan kerja, baik hubungan dengan atasan, hubungan dengan rekan kerja, 
maupun hubungan dengan bawahan (Sedarmayanti, 2006).

Kondisi kerja yang baik akan memengaruhi kinerja karyawan menjadi lebih tinggi (Rusti Mawa Praci, dkk. 2017). Di samping itu, kondisi kerja yang diberikan terhadap karyawan merupakan sarana yang dapat meningkatkan kinerja karyawan (Amelia Pratiwi, 2014).

Budaya organisasi juga merupakan variabel penting dalam meningkatkan kinerja karyawan karena budaya organisasi yang kuat akan meningkatkan kinerja karyawan (Siti Mujanah \& IA Brahmasari, 2019). Budaya organisasi merupakan suatu sistem yang memiliki nilai-nilai yang dianut oleh setiap anggota dalam suatu organisasi dan merupakan ciri khas tersendiri, yang membedakan suatu organisasi dengan organisasi lainnya (Robbins, Stephen P \& Judge, 2013). Definisi lain menyebutkan bahwa budaya organisasi sebagai sistem yang memiliki nilai-nilai dan merupakan keyakinan, asumsi-asumsi, atau nilai-nilai yang berlaku dan disepakati serta dianut oleh setiap anggota organisasi yang digunakan sebagai pedoman dalam berperilaku dan pemecahan suatu setiap permasalahan yang timbul dalam perusahaan atau organisasi (Sutrisno, 2011).

Budaya organisasi dapat diukur ke dalam empat elemen, yaitu managing change, achieving goals, coordinating teamwork, and cultural strength, dan ke empat elemen tersebut berpengaruh signifikan terhadap kinerja karyawan (Ghazi Ben Saad, 2018). Selain itu, budaya organisasi juga dapat diukur melalui indikator seperti employee participation, openness to communication, risk taking and innovation, customer service orientation, and reward system serta hasilnya adalah berpengaruh signifikan terhadap kinerja karyawan (Fakhar Shahzad, Zahid Iqbal, 2013). Budaya organisasi yang kuat dapat meningkatkan kinerja karyawan (Achmat Masku- rochman, Mulyanto Nugroho, Slamet Riyadi, 2020).

Dari pemahaman tersebut dapat dipahami sebagai suatu nilai, asumsi, sikap, dan norma perilaku yang diyakini oleh setiap anggota dalam organisasi kemudian digunakan sebagai pedoman dalam setiap langkah dalam melaksanakan kegiatan untuk mencapai kinerja yang tinggi sesuai dengan yang telah ditargetkan oleh perusahaan, dan budaya organisasi juga dapat digunakan sebagai identitas dari institusi organisasi.

Keberhasilan dari suatu organisasi sangat ditentukan oleh kinerja karyawan yaitu merupakan hasil dari pekerjaan organisasi yang dikerjakan oleh karyawan dengan sebaik-baiknya.

Setiap organisasi akan sukses apabila apa yang ditargetkan bisa tercapai, keberhasilan organisasi tidak lepas dari kinerja karyawan. Kinerja merupakan hasil yang diperoleh karyawan dalam menjalankan pekerjaannya baik secara kualitas dan kuantitas dalam melaksanakan tugasnya sesuai dengan tugas dan tanggung jawab yang diberikan kepada oleh perusahaan (Mangkunegara, 2016).

Kinerja dapat diartikan juga sebagai hasil kerja secara kualitas dan kuantitas dari seorang karyawan sebagai individu maupun kelompok dalam penyelesaian tugas sesuai dengan kemampuan yang diperoleh dari proses belajar serta keinginan untuk berprestasi (Khaerul Umam, 2010).

Dari berbagai pengertian tersebut maka dapat diambil suatu pemahaman yaitu merupakan hasil kerja yang diperoleh karyawan sesuai dengan target dan standar yang telah ditetapkan pada periode tertentu.

Berdasarkan kajian teori tersebut maka kerangka konseptual dalam penelitian ini dapat dilihat seperti pada Gambar 1. 


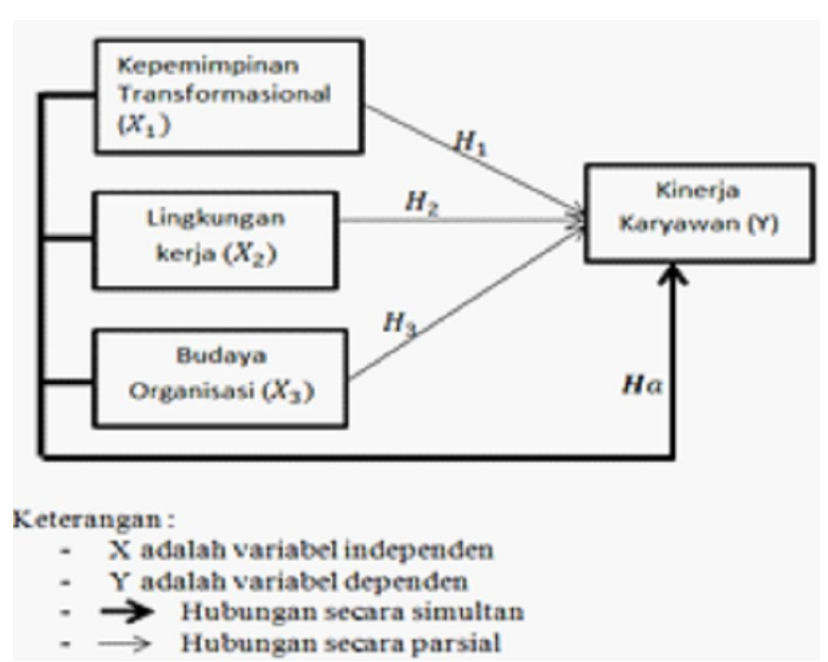

Gambar 1 Kerangka Konseptual

Berdasarkan Kajian teori dan kerangka konseptual tersebut maka hipotesis penelitian ini dapat dirumuskan sebagai berikut.

$H_{1}$ : Kepemimpinan transformasional berpengaruh positif dan signifikan terhadap kinerja karyawan.

$\mathrm{H}_{2}$ : Kondisi kerja berpengaruh positif dan signifikan terhadap kinerja karyawan.

$\mathrm{H}_{3}$ : Budaya organisasi berpengaruh positif dan signifikan terhadap kinerja karyawan.

\section{METODE PENELITIAN}

Penelitian ini menggunakan metode penelitian explanatory dengan pendekatan penelitian kuantitatif yaitu penelitian yang dilakukan dengan menguji hipotesis yang telah dirumuskan. Sumber data yang digunakan dalam penelitian ini adalah sumber data primer. Sedangkan Sampel perusahaan dalam penelitian ini adalah mengambil seluruh karyawan yang ada di Perusahaan Asuransi Central Asia Raya, Surabaya dengan pengambilan sampel secara sensus karena jumlah karyawan hanya 62 orang sehingga diambil semua karyawan sebagai responden dalam penelitian ini. Pengumpulan data dilakukan dengan metode survei dengan instrumen kuesioner, ja- waban responden dikategorikan dengan skala Likert $1-5$, yaitu skala penelitian yang digunakan untuk mengukur sikap atau pendapat responden dengan memilih jawaban yang sesuai dengan pendapat mereka terhadap pertanyaan (Nazir, 2005).

\section{HASIL PENELITIAN}

Jumlah responden dalam penelitian ini adalah 62 orang yang terdiri dari $60 \%$ Pria dan 40\% Wanita, dengan demikian komposisi pria dalam penelitian ini lebih dominan dari pada wanita. Dari 62 responden yang paling banyak dari mereka berusia antara 31-40 tahun yaitu sebanyak $45 \%$ sedangkan yang berusia 25-30 tahun ada $30,65 \%$ dan yang di atas 40 tahun hanya $19 \%$ sisanya atau usia di bawah 25 tahun hanya $5 \%$, hal ini menunjukkan bahwa yang menjadi responden ini kebanyakan berusia sekitar 25-40 tahun merupakan usia yang produktif dalam meraih kinerja.

Jika dilihat dari pendidikan responden kebanyakan berpendidikan S-1 yaitu sebesar 78\% sedangkan sisanya D-3 (4\%) dan SMA/SMK sebesar $19 \%$.

\section{Uji Validitas dan Reliabilitas Instrumen}

Pengujian instrumen dilakukan setelah data terkumpul dengan menguji validitas dan reliabilitasnya. Hasil uji validitas setiap kuesioner akan dinyatakan valid apabila nilai yang diperoleh mendapatkan angka di atas nilai r-tabel yaitu sebesar 0,2787. Setelah dilakukan uji korelasi ternyata hasilnya untuk setiap pertanyaan dalam kuesioner menunjukkan nilai $r_{\text {hitung }}$ lebih besar dari $r_{\text {table }}$, sehingga dapat dinyatakan bahwa semua item pertanyaan dalam kuesioner dinyatakan valid. 
Uji reliabilitas juga telah dilakukan terhadap instrumen yang digunakan. Hasil uji reliabilitas terhadap instrumen menunjukkan reliabel untuk semua pertanyaan yang membentuk suatu variabel dalam penelitian ini, karena nilai Cronbach's Alpha menunjukkan angka yang lebih besar dari 0.6 sehingga setiap pertanyaan yang membentuk setiap variabel dalam penelitian ini dinyatakan reliabel.

\section{Uji Asumsi Klasik}

Uji asumsi klasik digunakan sebagai syarat untuk menganalisis statistik parametrik, karena statistik yang digunakan dalam penelitian ini adalah uji regresi maka perlu di analisis dulu apakah data dalam penelitian ini berdistribusi normal, tidak adanya multikolinearitas, dan tidak ada heterocedastisitas.

\section{Uji Normalitas}

Uji Normalitas untuk mengetahui apakah data yang akan dianalisis telah memiliki persyaratan berdistribusi normal. Hasil analisis normalitas dapat dilihat pada Tabel 1.

Tabel 1 One-Sample Kolmogorov-Smirnov Test

\begin{tabular}{|ll|r|}
\hline & \multicolumn{1}{|c|}{$\begin{array}{c}\text { Unstandardized } \\
\text { Residual }\end{array}$} \\
\hline No & 62 \\
Normal & Mean & .000000 \\
Parameters & Std. Dev. & 1.3776368 \\
Most & Absolute & .072 \\
Extreme & Positive & .071 \\
Differences & Negative & -.075 \\
Kolmogorov-Smirnov Z & .517 \\
Asymp. Sign. (2-tailed) & .956 \\
\hline
\end{tabular}

Test distribution normal.

Sumber: data primer
Pengambilan kesimpulan dalam analisis uji normalitas dilakukan dengan cara membandingkan hasil uji normalitas dengan nilai alfa yang ditentukan sebesar 0,05 (Asymtotic Significant, 2 Tailed) sebagai berikut (Santoso, 2016).

Jika hasil perhitungan probability menunjukkan angka di atas 0,05 maka data dapat dinyatakan dalam kondisi berdistribusi normal.

Namun Jika hasil nilai probability menunjukkan angka di bawah 0,05 maka data dalam kondisi tidak distribusi normal.

Dari hasil pengujian satu sisi, dapat dinyatakan bahwa data dalam penelitian ini memiliki distribusi normal karena nilai prob. Sig menunjukkan angka sebesar 0,951 yaitu angka yang lebih besar dari $\alpha=5 \%(0.05)$ hal ini menunjukkan bahwa data dapat dikatakan berdistribusi normal, dengan kata lain bahwa data yang diperoleh dalam penelitian ini telah memenuhi persyaratan normalitas.

\section{Uji Multikolinearitas}

Uji Multikolinearitas digunakan untuk mengetahui apakah data memiliki menunjukkan ada atau tidaknya multikolinearitas antar-variabel bebas, hasil analisis dapat dilihat pada Tabel 2.

Tabel 2 Hasil Analisis Variance Inflation Factor

\begin{tabular}{|l|l|l|}
\hline Variabel & Tolerance & VIF \\
\hline Kepemimpinan & & \\
Transformasional & 0,731 & 1.386 \\
Kondisi kerja & 0,550 & 2.813 \\
Budaya Organisasi & 0,573 & 2.748 \\
\hline
\end{tabular}

Sumber: Diolah Penulis

Tabel 2 menunjukkan hasil perhitungan multikolinearitas yang dapat dilihat dari hasil VIF, di mana variabel kepemimpinan transformasional, kondisi kerja, dan budaya organisasi 
mempunyai nilai tolerance di atas 0,1 dan nilai VIF $<10$ sehingga hasil uji multikolinearitas menunjukkan bahwa data dalam penelitian ini tidak terdapat multikolinearitas antar variabel bebas.

\section{Uji Heterokedastisitas}

Uji Heterokedastisitas adalah suatu uji asumsi yang merupakan salah satu persyaratan dalam penggunaan regresi agar model regresi tidak bisa untuk mengetahui apakah terdapat ketidaksamaan varian dari residual dalam semua pengamatan pada model regresi. Hasil analisis heterakedastisitas dapat dilihat pada Gambar 2.

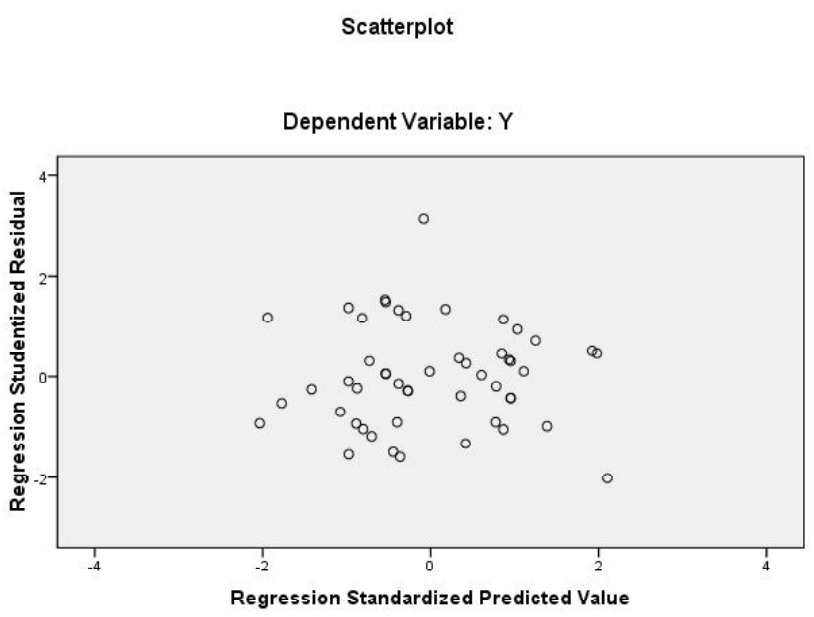

Gambar 2

Gambar 2 menunjukkan bahwa tidak ada Heteroskedastisitas karena gambar menunjukkan titik-titik yang menyebar di atas dan di bawah angka 0 sehingga tidak ada pola yang jelas.

\section{Uji Regresi Berganda}

Regresi berganda digunakan untuk mengetahui besarnya pengaruh variabel independen $X$ terhadap variabel dependen Y. Hasil analisis regresi berganda dapat dilihat pada Tabel 3 .
Tabel 3 Analisis Regresi Linier Berganda

\begin{tabular}{|c|c|c|c|c|c|c|}
\hline & \multirow{2}{*}{ Model } & \multicolumn{2}{|c|}{$\begin{array}{l}\text { Unstandardized } \\
\text { Coefficients }\end{array}$} & \multirow{2}{*}{\begin{tabular}{|c|}
$\begin{array}{c}\text { Standardized } \\
\text { Coefficients }\end{array}$ \\
Beta
\end{tabular}} & \multirow{2}{*}{$\mathbf{t}$} & \multirow{2}{*}{ Sig. } \\
\hline & & B & $\begin{array}{l}\text { Std. } \\
\text { Error }\end{array}$ & & & \\
\hline \multirow[t]{4}{*}{1} & (Constant) & 3.824 & 1.755 & & 2.175 & .036 \\
\hline & Kep Transf. & .153 & .062 & .256 & 2.414 & .021 \\
\hline & $X-2$ & .162 & .051 & .384 & 3.153 & .004 \\
\hline & $x-3$ & .156 & .061 & .312 & 2.602 & .013 \\
\hline
\end{tabular}

a. Dependent Variable: $Y$

Sumber: Data Primer diolah Penulis

Tabel 3 menunjukkan hasil analisis regresi berganda yang menunjukkan persamaan sebagai berikut.

$Y=3.824+0,153 X 1+0,162 X 2+0,156 X 3+e$

Dari hasil persamaan regresi tersebut maka dapat diinterpretasikan sebagai berikut.

1. Nilai konstan (a) menunjukkan angka sebesar 3.824 , artinya bahwa nilai kinerja karyawan (Y) adalah 3.824 apabila tanpa disertai adanya variabel kepemimpinan transformasional, kondisi kerja, dan budaya organisasi.

2. Kepemimpinan transformasional menunjukkan nilai koefisien ( $\beta 1$ ) sebesar 0,153 , artinya bahwa variabel kepemimpinan transformasional ( $\beta 1)$ mengalami peningkatan maka akan berdampak pada peningkatan kinerja karyawan sebesar 0,152 dengan asumsi variabel lain konstan. Dengan demikian dapat dikatakan bahwa kepemimpinan transformasional berpengaruh terhadap kinerja karyawan.

3. Kondisi kerja menunjukkan nilai koefisien sebesar 0,161 , artinya apabila variabel kondisi kerja mengalami peningkatan satu satuan, maka akan berdampak pada peningkatan kinerja karyawan sebesar 0,161 . Hal ini menunjukkan bahwa kondisi kerja memiliki pengaruh terhadap kinerja karyawan. 
4. Budaya Organisasi memiliki nilai koefisien regresi sebesar 0,155 yang menunjukkan bahwa apabila budaya organisasi di tingkatkan satu satuan, maka berdampak pada peningkatan kinerja karyawan sebesar 0,155 , sehingga dapat dikatakan bahwa buaya organisasi berpengaruh terhadap kinerja karyawan.

Dari hasil analisis regresi linier berganda tersebut maka dapat diketahui bahwa kepemimpinan transformasional, kondisi kerja, dan budaya organisasi berpengaruh positif terhadap kinerja karyawan. Akan tetapi, apakah pengaruh tersebut signifikan atau tidak maka perlu di uji lebih lanjut dengan menggunakan Uji F dan Uji-t.

\section{Koefisien Korelasi dan Determinasi}

Koefisien korelasi digunakan untuk mengetahui seberapa erat hubungan antara variabel $X$ dengan variabel $Y$ dalam penelitian ini.

Tabel 4 Model Summary

\begin{tabular}{|c|c|c|c|c|}
\hline Model & $\mathrm{R}$ & $\begin{array}{c}\mathrm{R} \\
\text { Square }\end{array}$ & $\begin{array}{c}\text { Adjusted } \\
\mathrm{R} \text { Square }\end{array}$ & $\begin{array}{c}\text { Std. Err. of the } \\
\text { Est. }\end{array}$ \\
\hline 1 & $.792^{\mathrm{a}}$ & .627 & .603 & 1.422 \\
\hline
\end{tabular}

a. Predictors: (Constant), X3, X2, X1

b. Dependent Variable: $Y$

Hasil perhitungan melalui program SPSS menunjukkan bahwa nilai koefisien korelasi $(R)$ sebesar 0.792 artinya secara bersama-sama bahwa kepemimpinan transformasional, kondisi kerja, dan budaya organisasi memiliki hubungan yang positif dan kuat dengan kinerja karyawan. $\mathrm{Hal}$ ini dapat dilihat dari hasil analisis korelasi yang mendapatkan angka sebesar 0,792 , artinya apabila kepemimpinan transformasional, kondisi kerja, dan budaya organisasi ditingkatkan maka kinerja karyawan juga akan meningkat, demikian juga sebaliknya.
Sedangkan hasil analisis determinasi atau R2 menunjukkan angka sebesar 0,627 atau $62,70 \%$ yang menunjukkan bahwa kepemimpinan transformasional, kondisi kerja karyawan, dan budaya organisasi memiliki peran sebesar $62,70 \%$ terhadap pencapaian kinerja karywan, sedangkan sisanya sebesar $37.3 \%$ dijelaskan oleh faktor lain di luar model, kemungkinannya bisa variabel kemampuan kerja, kompetensi, semangat kerja, dan mungkin variabel lain.

\section{PENGUJIAN HIOTESIS}

\section{Hasil Uji-t (Parsial)}

Pengujian hipotesis secara partial telah dilakukan dengan uji-t, di mana hasilnya ditunjukkan pada Tabel 3.

Analisis uji t untuk menguji hipotesis yang berbunyi kepemimpinan transformasional berpengaruh signifikan terhadap kinerja karyawan menunjukkan angka $t_{\text {nitung }}$ sebesar 2.414 menunjukkan angka yang lebih besar dari $t_{\text {tabel }}$ sebesar 2.0129 dan nilai signifikan menunjukkan angka sebesar 0.020 lebih besar dari 0,05, sehingga dapat disimpulkan bahwa kepemimpinan transformasional berpengaruh signifikan terhadap kinerja karyawan.

Hipotesis kedua yang menyatakan bahwa kondisi kerja berpengaruh signifikan terhadap kinerja karyawan menunjukkan hasil bahwa $t_{\text {hitung }}$ sebesar 3.153 yang menunjukkan angka lebih besar dari $t_{\text {tabel }} 2.0129$, sedangkan nilai probability signifikansi sebesar 0.003 menunjukkan angka lebih besar dari 0.05 sehingga dapat dikatakan bahwa kondisi kerja berpengaruh signifikan terhadap kinerja karyawan.

Hipotesis ketiga adalah budaya organisasi berpengaruh signifikan terhadap kinerja karyawan terbukti kebenarannya karena hasil uji $t$ menunjukkan angka $t_{\text {hitung }}$ sebesar 2.602 meru- 
pakan angka yang lebih besar dari $t_{\text {tabel }} 2.0129$ dan nilai probability signifikansi sebesar 0.012 lebih besar dari 0.05 sehingga dapat dikatakan bahwa budaya organisasi berpengaruh signifikan terhadap kinerja karyawan.

\section{Hasil Uji-F (Uji Simultan)}

Uji-F digunakan untuk menguji hipotesis secara simultan, hasil perhitungan uji $F$ dapat dilihat pada Tabel 5.

Tabel 5: Hasil Analisis AN OVA

\begin{tabular}{|l|r|r|r|c|c|}
\hline Model & $\begin{array}{c}\text { Sum of } \\
\text { Squares }\end{array}$ & df & $\begin{array}{r}\text { Mean of } \\
\text { Square }\end{array}$ & F & Sig. \\
\hline 1 Regression & 156.285 & 3 & 52.094 & 25.767 & $.000^{a}$ \\
Residual & 92.997 & 46 & 2.021 & & \\
Total & 249.281 & 49 & & & \\
\hline
\end{tabular}

a. Predictors: (Constant), $X 3, X 1, X 2$

b. Dependent Variable: $Y$

Tabel 5 menunjukkan nilai hasil uji F-hitung sebesar 25.768 sedangkan F-tabel sebesar 2,80, sedangkan nilai probability signifikansi sebesar $0.000<0.05$, hal ini menunjukkan bahwa kepemimpinan transformasional, Kondisi kerja, dan budaya organisasi secara simultan berpengaruh positif dan signifikan terhadap kinerja karyawan.

\section{PEMBAHASAN}

\section{Pengaruh Kepemimpinan Transformasional Ter- hadap Kinerja}

Hasil analisis menunjukkan bahwa kepemimpinan transformasional memiliki pengaruh yang positif dan signifikan terhadap kinerja karyawan, artinya bahwa Perusahaan Asuransi Central Asia Raya Surabaya telah menerapkan kepemimpinan transformasional sehingga membuat karyawan memiliki kepercayaan, kekagum- an, kesetiaan, dan penghormatan terhadap pemimpinnya, dengan begitu karyawan dapat mencapai kinerja yang lebih tinggi. Hal ini mendukung penelitiannya Anhairullah (2016) dan Endri Sukmana dkk. (2015).

Temuan tersebut mengindikasikan bahwa dalam upaya untuk meningkatkan kinerja karyawan yang lebih tinggi maka diperlukan penerapan kepemimpinan transformasional terhadap karyawan sehingga dapat termotivasi untuk mencapai kinerja yang lebih tinggi.

Selain itu, kepemimpinan transformasional mampu memotivasi karyawan untuk mencapai target yang telah ditetapkan sehingga kinerja dapat di peroleh secara optimal.

\section{Pengaruh Kondisi Kerja Terhadap Kinerja}

Hasil analisis regresi menunjukkan bahwa kondisi kerja berpengaruh positif dan signifikan terhadap kinerja karyawan. Hasil ini membuktikan bahwa dengan adanya pemberian fasilitas kerja seperti penerangan/ cahaya di tempat kerja cukup, suhu dan sirkulasi udara yang tepat, tidak ada gangguan suara, bau-bauan, tata warna dan dekorasi yang indah, aman, dan adanya hubungan yang baik antar-karyawan maka akan membuat karyawan di PT AJ Central Asia Raya Cabang Surabaya dapat bekerja dengan optimal dan kinerjanya bisa meningkat.

Hasil penelitian ini mendukung hasil penelitiannya Rusti Mawa Praci, Yuliana, dan Hijriyantomi Suyuthie (2017), bahwa kondisi kerja berpengaruh terhadap kinerja karyawan (Amelia Pratiwi, Nuryanti dan Iwan N. Daulay, 2014).

\section{Pengaruh Budaya Organisasi Terhadap Kinerja Karyawan}

Pembuktian hipotesis yang telah dilakukan menghasilkan bahwa budaya organisasi berpenga- 
ruh positif dan signifikan terhadap kinerja karyawan, dengan demikian dapat dinyatakan bahwa hipotesis terbukti kebenarannya. Hal ini menunjukkan bahwa penerapan budaya organisasi yang kuat dan budaya dapat diterima dan dilaksanakan oleh semua anggota organisasi maka karyawan akan bekerja dengan baik.

$\mathrm{Hal}$ itu menunjukkan bahwa penerapan budaya organisasi dengan memperhatikan halhal seperti Inovasi dan pengambilan risiko, adanya perhatian, berorientasi pada hasil, orang, teamwork, dan terbentuk keagresifan serta kemantapan atau stabilitas yang selalu di jaga sehingga karyawan dapat mencapai kinerja yang lebih tinggi.

Hasil penelitian ini mengindikasikan bahwa budaya organisasi secara positif dan signifikan berpengaruh terhadap kinerja kerja karyawan. Oleh karena itu, hasil penelitian ini mendukung hasil penelitiannya Alinvia Ayu Sagita Heru Susilo Muhammad Cahyo W.S., 2018) bahwa budaya organisasi berpengaruh positif dan signifikan terhadap kinerja karyawan dan hasil penelitiannya (Siti Mujanah, dkk) bahwa budaya organisasi berpengaruh signifikan terhadap kinerja.

\section{SIMPULAN DAN REKOMENDASI}

Berdasarkan rumusan masalah dan hasil analisis data dalam penelitian ini dapat ditarik simpulan guna menjawab rumusan masalah, antara lain kepemimpinan transformasional berpengaruh signifikan terhadap kinerja karyawan; kondisi kerja berpengaruh signifikan terhadap kinerja karyawan; dan budaya organisasi berpengaruh signifikan terhadap kinerja karyawan. Hal itu menunjukkan bahwa kepemimpinan transformasional, kondisi kerja, dan budaya organisasi harus diperhatikan dalam memotivasi sumber daya manusia di perusahaan, karena dengan penerapan kepemimpinan transformasional yang tepat, kondisi kerja yang nyaman, dan memperlakukan budaya organisasi yang kuat akan dapat meningkatkan kinerja yang lebih baik.

\section{REKOMENDASI}

Berdasarkan simpulan tersebut maka beberapa rekomendasi dapat diberikan, seperti penerapan gaya kepemimpinan transformasional yang tepat akan memotivasi karyawan dalam meningkatkan kinerja mereka, demikian juga perusahaan harus mempersiapkan kondisi kerja yang nyaman karena bekerja di kantor asuransi akan banyak berhubungan dengan klien yang harus dilayani dengan baik sehingga kondisi kerja yang nyaman akan membawa pelayanan menjadi lebih baik. Selain itu, budaya organisasi harus diciptakan dengan kuat karena dengan budaya organisasi yang kuat dapat meningkatkan kinerja karyawan di perusahaan.

Selanjutnya, hasil penelitian ini dapat digunakan sebagai referensi bagi peneliti yang akan melakukan penelitian dalam bidang SD M dengan variabel yang similar seperti kemampuan kerja, kompetensi, semangat kerja, dan variabel lain.

\section{DAFTAR PUSTAKA}

Achmat Maskurochman, Mulyanto Nugroho, \& Slamet Riyadi. 2020. The Influence of Transformational Leadership, Organizational Support, and Job Satisfaction on Motivation and Employee Performance. JMM17 Jurnal Ekonomi dan Manajemen, $7(1)$.

Alex S. Nitisemito. 2014. Manajemen Personalia. Jakarta: PT Galia Indonesia.

Amelia Pratiwi, N. dan I.N.D. 2014. Pengaruh Lingkungan Kerja dan Budaya Organisasi 
terhadap Kinerja Karyawan PT Bank Riau Kepri Capem Duri. Jom FEKON, 1(2). Anhairullah \& Siti Mujanah. 2016. Pengaruh Gaya Kepemimpinan Transformasional dan Lingkungan Kerja Terhadap Kinerja Karyawan pada Pengadilan Negeri Kelas 1B Raba Bima. Jurnal Riset Ekonomi dan Manajemen, 16(1), pp. 15-28.

Delvin Alexander Gunawan, S.M. \& M. 2018. Pengaruh Hubungan Interpersonal, Lingkungan Kerja, dan Perceived Organizational Support terhadap Motivasi Kerja dan Kinerja Karyawan PT Mitra Surya Persada. Jurnal Global, 2(2), pp. 11-22.

Endri Sukmana dan Gede Adyana Sudibia. 2015. Pengaruh Kepemimpinan Transformasional, Motivasi, dan Burnout terhadap Kinerja Karyawan Outsourcing Rri Mataram. E-Jurnal Manajemen Unud, Vol. 4, No. 8. Fakhar Shahzad \& Zahid Iqbal, M.G. 2013. Impact of Organizational, Culture on Employees Job Performance: An Empirical Study of Software Houses in Pakistan. Journal of Business Studies Quarterly, Vol. 5, No. 2, Pg. 56-64.

Firdaus Djaelani. 2011. Pertumbuhan Industri Asuransi Jiwa di Indonesia: Suatu Kajian dari Sisi Penawaran, Jurnal Ilmiah Sosial dan Humaniora. Jurnal Ilmiah Sosial dan Humaniora, 1(3).

Ghazi Ben Saad, M.A. 2018. The Impact of Organizational Culture on Job Performance: A Study of Saudi Arabian Public Sector Work Culture. Problems and Perspectives in Management, 16(3).

Khaerul Umam. 2010. Perilaku Organisasi, Cetakan 1. Bandung: CV Pustaka Setia.

Khan, Zunnoorain, Shahzad Khan, \& S.S. 2013. Moderating Role of Procedural Justice and Empowerment in Transformational
Leadership with its Impact on Organizational Commitment. International Review of Management and Business Research, 2(3), pp. 847-852.

Mangkunegara, A.A.P. 2016. Manajemen Sumber Daya Manusia Perusahaan. Bandung: PT Remaja Rosdakarya.

Nazir, M. 2005. Metode Penelitian. Jakarta: PT Ghalia Indonesia.

Nisrina Salma Alifah. 2020. Data Perkembangan Asuransi di Indonesia. Available at: lifepal. co.id-media>data>perkembangan-asuransidi-i.

Robbins, Stephen P. \& Coulter, M. 2010. Manajemen, Edisi Kesepuluh. Jakarta: Penerbit Airlangga.

Robbins, Stephen P. \& Judge, T.A. 2013. Organizational Behavior, Terjemahan Ratna Saraswati dan Fabriella Sirait, Edition 16. Jakarta: Salemba Empat.

Santoso, S. 2016. Panduan Lengkap SPSS Versi 23. Jakarta: Elexmedia Computindo.

Sedarmayanti. 2006. Sumber Daya Manusia dan Produktivitas Kerja. Bandung: Mandar Maju.

Siti Mujanah, I.A. Brahmasari, I.B.R., \& C. 2019. The Impact of Collective Ambition, Organizational Culture, and Organizational Commitment on Organizational Citizenship Behavior and the Women's Cooperatives' Performance in East Java Indonesia. International Journal of Civil Engineering, 10(08), pp. 30-44.

Sutrisno, E. 2011. Manajemen Sumber Daya Manusia. Jakarta: PT Kencana.

Tria Mondiana. 2012. 'Pengaruh Kepemimpinan Transformasional dan Kompensasi terhadap Kinerja Karyawan PT PLN (Persero) UPJ Semarang. Jurnal Administrasi Bisnis, $1(1)$. 